\title{
STUDY OF STUDENTS' VOCABULARY DIFFICULTIES IN THIRD-SEMESTER STUDENTS OF FOOD TECHNOLOGY MAJOR
}

\author{
Juliana Sujadi ${ }^{1}$, Fariska Wulandari² \\ ${ }^{1,2}$ English for Business and Professional Communication, Politeknik Tonggak Equator \\ Jalan Fatimah Nomor 1-2, Pontianak Kota, Pontianak, Kalimantan Barat \\ 2e-mail: RiskaDiandra0212@gmail.com
}

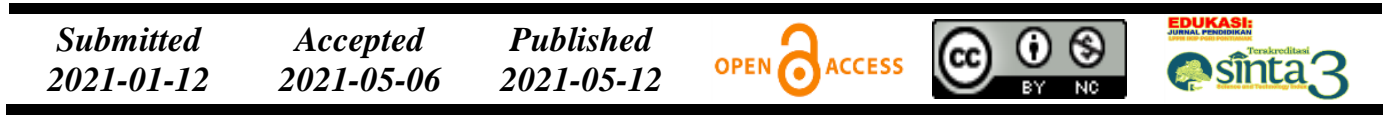

\begin{abstract}
This research aimed to know the students' vocabulary ability and difficulties in learning vocabulary. The subject of the research was the third-semester students of Food Technology. The method used in this research is descriptive qualitative with questionnaire and interview as the instruments of data collecting. The data was analyzed qualitatively with the process of data collection, data reduction, and data display/conclusion drawing. The result of the research showed the students still have low vocabulary ability and there are some vocabulary difficulties experienced by the students, they have a very limited number of vocabularies; mispronounce English words; spelling English words especially for 'a', 'I', and 'e'; do not understand long and complex words such as public health center, expired date, and fish spoilage. The students also have problems with range, connotation, and idiom in English.
\end{abstract}

Keywords: vocabulary; vocabulary difficulties; descriptive qualitative.

\begin{abstract}
Abstrak
Penelitian bertujuan untuk mengetahui kemampuan kosakata dan kesulitan mahasiswa dalam belajar kosakata bahasa Inggris. Subjek penelitian adalah mahasiswa semester tiga Jurusan Teknologi Pangan. Metode penelitian menggunakan deskriptif kualitatif dengan kuesioner dan wawancara sebagai instrumen pengumpulan data. Data hasil penelitian dianalisis secara kualitatif dengan tahap pengumpulan data, pengurangan data, dan penarikan kesimpulan. Hasil penelitian menunjukkan mahasiswa semester tiga Jurusan Teknologi Pangan Politeknik Tonggak Equator memiliki kemampuan kosakata bahasa Inggris yang rendah dan terdapat beberapa kesulitan belajar kosakata yang dihadapi yaitu memiliki pembendaharaan kosakata bahasa Inggris yang rendah, memiliki kesulitan dalam pelafalan dan pengejaan ' $a$ ', 'I', dan ' $e$ ', tidak mengerti kosakata yang panjang dan rumit, memiliki masalah dengan penerjemahan. Mahasiswa juga memiliki masalah dengan penyusunan kata, konotasi, dan idiom dalam Bahasa Inggris.
\end{abstract}

Kata Kunci: kosakata; kesulitan belajar kosakata; deskriptif kualitatif.

\section{INTRODUCTION}

Vocabulary is a bunch of words that the users use differently (Hatch \& Brown, 1995). The ability of vocabularies will show the progress of the learners' in learning vocabulary (Schmitt, 2000). Vocabulary is fundamental in learning a 
Edukasi: Jurnal Pendidikan, Volume 19 Nomor 1 Tahun 2021

Study of Students' Vocabulary Difficulties.......

Juliana Sujadi, Fariska Wulandari

Halaman 90-104

language since with vocabularies, students are able to understand reading passages in their textbook (Bakhsh, 2016). Vocabulary is central to the learning and teaching of a second language as it affords learners access to both oral and written communication. Words knowledge is power as words serve as building blocks to learning. It means that learning vocabulary is a must for students who learn a certain language since it is really important in accessing both oral and written communication (Moeller et al., 2009). The role of vocabulary in language use is clear because it is an inseparable aspect of every language (Astika, 2016). Vocabulary helps people read and listen with more understanding.

Vocabulary helps people to express themselves better when they speak to other people or write a message. A previous study said that vocabulary is dominant in improving a person's communication skills (Anil, 2011). Then, vocabulary has an important role since it is related to the four language skills (Ramadhaniarti, 2016). Before students master the four skills, they need to know some vocabularies to support them in learning English. Vocabulary is an integrated part of learning a language because the increased learner vocabulary, the better their speaking and writing will be (Bin-Tahir, 2015). Moreover, learning and increasing number of vocabulary are very essential because English proficiency depends on the knowledge of vocabulary that possessed by the second and foreign learners and even native speaker (Afzal, 2019).

Vocabulary is essential both in second and foreign language acquisition because without correct and enough vocabulary learners cannot understand what other people say and they will not be able to express their own feelings (Viera, 2017). Vocabulary learning is a prominent part of foreign language teaching and learning. It is also necessary for a language learner (Alqahtani, 2015). Vocabulary plays a more significant role than grammar. People need to use words in order to tell or express feelings and ideas in any language, as well as students (Wilkins, 1972). Successful people usually have a large number of vocabularies and a good ability in selecting and recognizing the word (Hancock, 1987).

Vocabulary development is very significant for both ways of communicating, speaking, and writing. If the students do not understand what the 
lecturer says, one of the reasons could be because they do not understand the words (Hancock, 1987). In researcher's experience as a lecturer, she noticed the fact that students are usually hard to understand the reading text given by the lecturer, hard to speak English fluently and keep on using the same words, and oftentimes, their conversation is interrupted due to missing words. And the main reason for those communication problems is the lack of vocabulary. Consider the very significant role of vocabulary and the low vocabulary performance of the students encourage the researcher analyzes the students' ability and problems in learning vocabulary in order to know the vocabulary ability and their difficulties in learning vocabularies.

This research focused on the students' ability and difficulties in learning vocabulary. Vocabulary is very important because it is the starting point that people have to aware of when they dealing with languages (Al-Hinnawi, 2012). Vocabulary is a set of words in oral and written and in productive and receptive which has meaning (Lehr et al., 2004). Moreover, vocabulary is the focus of language with its sounds and intended meanings that allow students to communicate with others. In classroom implementation, vocabulary becomes the guidance that leads students to comprehend every piece of information both oral and written, and to produce ideas and thought (Nation, 2000; Pyles, 1970).

There are two types of vocabulary related to language skills they are receptive vocabulary which refers to the words that native speakers and foreign learners understand but it seldom used, and productive vocabulary which is used actively both in speaking and writing (Thornbury, 2002; Nation, 2001). Identify the students' difficulties in learning vocabulary is important. In the process of learning vocabulary, students face 4 difficulties, they are pronouncing unique English sounds, spelling, memorizing long syllable words, and understanding the the meaning of unfamiliar words (Salam \& Nurnisa, 2021). Some factors that make words more difficult are: pronunciation; spelling; length and complexity; grammar; meaning; range; connotation; and idiomaticity (Thornbury, 2004).

Words that are difficult to pronounce are more difficult to learn. Words that contain silent letters can be difficult for learners such as foreign, listen, headache, 
bored, honest, muscle, etc. Long words are more difficult to learn than short ones but, high-frequency words tend to be short in English, and therefore the learner is likely to meet them more often. Grammar associated with a word that differs from L1 also will be difficult for learners. Remembering whether a verb like enjoy, love, or hope is followed by an infinitive (to swim) or an -ing form (swimming) can be a difficulty for a student. Fifth, meaning. When two words overlap in meaning, learners can be confused, for example, the word makes and do: you make breakfast and make an appointment, but you do the housework and do a questionnaire. Words that can be used in a wide range of contexts will be easier than their synonyms with a narrower range. Thus, put is a very wide-ranging verb, compared to impose, place, position, etc. Thin is safer than skinny, slim, slender. Uncertainty as to the connotations of some words may cause problems too. Thus, propaganda has negative connotations in English, but its equivalent may simply mean publicity. On the other hand, eccentric does not have negative connotations in English, but its nearest equivalent in other languages may be deviant. Finally, words or expressions that are idiomatic (like make up your mind, keep an eye on) will be more difficult than words whose meaning is transparent (decide, watch).

\section{METHOD}

This research was descriptive qualitative research that was conducted in Tonggak Equator Polytechnic. The subjects of this study were the third-semester students of Food Technology Major of Tonggak Equator Polytechnic in the academic year 2018-2019 that consisted of 24 students and an English lecturer who become the interviewee. The researcher used a questionnaire and interview guidelines as the instruments of data collection. The questionnaire is used to collect students' opinions related to their difficulties in learning vocabulary and to supply the necessary information to complete the study.

The indicators of the questionnaire and interview questions about students' vocabulary difficulties, they are: pronunciation; spelling; length and complexity; grammar; meaning; range; connotation; and idiomaticity (Thornbury, 2004). The researcher distributed questionnaires to 24 respondents and used depth interviews 
in collecting the data. Then, the result of the questionnaire and interview sheet was analyzed qualitatively. The data was analyzed qualitatively with the process of data collection, data reduction, and data display/conclusion drawing.

\section{RESULT AND DISCUSSION}

Based on the result of the interview with the English lecturer, it can be said that the students have a very weak vocabulary skill, have a very limited vocabulary, have difficulty memorizing the vocabulary given for telling about the daily routine, cannot make proper sentences without a dictionary. When they have to make the same sentences without a dictionary, they will just give up as they do not remember the vocabulary. The following is a transcript of the interview.

$\begin{array}{ll}\text { Researcher } & \text { : 'According to you, how is the students' vocabulary } \\ \text { ability in your English class?" } \\ \text { English Lecturer } & \text { :"The students have very weak vocabulary skills. The } \\ & \text { students have a very limited vocabulary. They have } \\ & \text { difficulty memorizing the vocabulary given for telling } \\ & \text { about their daily routine such as feed the cat, walk the } \\ & \text { dog, arrive at school, make the bed, etc. Besides, they } \\ & \text { can't make proper sentences without a dictionary. } \\ & \text { When they have to make the same sentences without a } \\ & \text { dictionary, they will just give up as they don't } \\ & \text { remember the vocabulary." }\end{array}$

Then, students more often mispronounce English words. One of the factor that made some words more difficult is pronunciation. The following is a transcript of the interview.

Researcher : "Do they able to pronoun English words correctly?"

English Lecturer : "Sometimes. More often they mispronounce English words. For instance, they say/grit/for great."

The students also still have difficulty in spelling English words correctly especially for the sound 'a', 'I', and 'e'. How to write a word and how to spell is one of the students' problems in learning vocabulary (Thornbury, 2004). The following is a transcript of the interview.

Researcher : "Do they able to spell their names or English words correctly?"

English Lecturer : "They still have difficulty in spelling the English words especially for a, i, and e. Sometimes, they also have 
difficulty spelling several words such as honest, straight, thought, etc. If they have to write those words, they just write what they hear such as 'anes' for 'honest'."

Length and complexity are also the factors that make some words more difficult. A long word is more difficult to understand by the learners than a short one (Hariyanto \& Wulandari, 2019; Thornbury, 2004). Students do not understand long and complex words such as public health center, expired date, fermentation, fish spoilage, etc. as well. Many of them translate the vocabulary word by word.
Researcher : "Do they know and understand long and complex words such as public health center, expired date, fermentation, fish spoilage, etc.?"
English Lecturer : "No. Even for telling about their daily activity they still have difficulty. Besides, many of them translate the vocabulary word by word. For example, when they have the words "to walk the dog" they will translate it in Bahasa as 'jalan anjing' or 'anjing berjalan'. So, it is more difficult for them to understand the long complex words."

Based on the interview, it can be said that students have problems with vocabularies. As a result, they struggle to communicate what they are thinking. Besides, as their vocabulary is very limited, they tend to use the same word in their writing.

Researcher : "According to you, do they have problems with their vocabularies?"

English Lecturer : “Absolutely. As a result, they struggle to communicate what they are thinking. Besides, as their vocabulary is very limited, they tend to use the same word over and over again in their writing."

Then, in the interview with the English lecturer, the lecturer said that the students' vocabulary problems were they have limited vocabulary and cannot build up a different form of the word.

Researcher : "What is/are their vocabulary problem/problems?"

English Lecturer : "Limited vocabulary. In addition, they are not able to build up a different form of the word."

The students also have problems with grammar. According to the English lecturer, the students' grammar abilities were very poor. The problems of their 
grammar are tenses use, the plural form, and preposition. For example, they say "My class is in the second floor." They use 'in' instead of 'on'. In the simple present tense, the students cannot make a sentence properly. On the other hand, when they move to learn other tenses they will get confused and forget what they have learned. Then, they still make mistakes in a plural sentence. They still get confused on how to make positive and interrogative sentences of simple present tense where they have to add $-\mathrm{s}$ or -es to the verb for the third singular person. Students were hard to understand and use grammar patterns correctly. It likely becomes one of the students' problems in learning vocabulary (Thornbury, 2004). The different grammatical form of the word is one of the causes students' problems in learning vocabulary.

$\begin{array}{ll}\text { Researcher } & \text { : "According to you, how is their grammar ability?" } \\ \text { English Lecturer } & \text { "'Their grammar is very poor. When they have just } \\ & \text { learned about it (eq. simple present tense) they can't } \\ & \text { make a sentence properly. On the other hand, when } \\ & \text { they move to learn other tenses they will get confused } \\ & \text { and forget what they have learned. In addition, they still } \\ & \text { make mistakes in a plural sentence. As an example they } \\ & \text { say 'two person', not 'two people'." } \\ \text { : "Do they able to make simple present tense sentences } & \\ \text { Researcher } & \text { correctly?" } \\ \text { English Lecturer } \quad \text { "They still get confused on how to make a positive } & \\ & \text { sentence where they have to add -s or -es to the verb } \\ & \text { for the third singular person. For example, many of } \\ & \text { them write 'my mother fry chicken every Saturday'. } \\ & \text { Besides, they still have a problem in making an } \\ & \text { interrogative sentence. For instance, they write 'Yo } \\ & \text { want to go? Yes, I do.' In addition, for the students who } \\ & \text { have poor vocabulary and grammar ability they write } \\ & \text { 'my mother fried chicken every Saturday'." }\end{array}$

Students cannot make simple past tense sentences correctly as well. Most of them still have problem with memorizing the past form of verb especially for irregular verbs.

Researcher : "Do they able to make simple past tense sentences correctly?"

English Lecturer : "No, they don't. Only a few students can do it well. Most of them still have problems with memorizing the past form of the verb, especially for irregular verbs. 
Even it can still be found that the students write past form of 'go' become 'when' instead of 'went'."

Students are able to make future tense sentences correctly. Unfortunately, when they have to make a sentence using an adjective or noun, they make errors by generalizing the rule. The finding supported by the interview transcript below.

Researcher : "Do they able to make future tense sentences correctly?"

English Lecturer : "Yes, they do. They are able to make a sentence in the future tense, but when they have to make sentence using adjective or noun they make a mistake by generalizing the rule. For example, they write 'I will sick' instead of 'I will be sick'."

The grammar problem which is the most frequent is tenses use. According to the English lecturer, the most frequent problem is tenses use especially simple present tense and simple past tense.

Researcher : "Which grammar problems are the most frequent?"

English Lecturer : "Tenses use, especially for Simple present and simple past."

Students also have problems with translation. They are able to translate English vocabulary but they have to use a dictionary on their smartphone. They also have problems with range, connotation, and idiom in English. The finding supported by the following interview transcript.

Researcher : :Do they able to translate English vocabularies such as rice field, plant, pour, seed, root correctly?"

English Lecturer : "Yes, but they have to use a dictionary on their phone."

Researcher : "Do they understand range, connotation, and idiom in English? “

English Lecturer : "They have no idea about it. They just know simple words."

Then, the result of the questionnaire can be seen in Table 1.

Table 1 Students can Pronounce English Vocabulary Well

\begin{tabular}{cc}
\hline Answer Choice & Percentage \\
\hline Can & $50 \%$ \\
Can't & $50 \%$ \\
\hline Total & $\mathbf{1 0 0 \%}$ \\
\hline
\end{tabular}


Table 1 shows that only $50 \%$ of students can pronounce English vocabulary well while others not. Therefore, they need to improve their skill in pronouncing English vocabulary.

Table 2 Students can Spell English Vocabulary Well

\begin{tabular}{cc}
\hline Answer Choice & Percentage \\
\hline Can & $62.5 \%$ \\
Can't & $37.5 \%$ \\
\hline Total & $\mathbf{1 0 0 \%}$ \\
\hline
\end{tabular}

Table 2 shows $62.5 \%$ of students can spell English vocabulary well while $37.5 \%$ can't spell English vocabulary well. It means that there are still $37.5 \%$ of students who need to improve their English spelling.

Table 3 Students can Understand and Use Long and Complicated English Vocabulary

\begin{tabular}{cc}
\hline Answer Choice & Percentage \\
\hline Can & $37.5 \%$ \\
Can't & $62.5 \%$ \\
\hline Total & $\mathbf{1 0 0 \%}$ \\
\hline
\end{tabular}

Table 3 shows that $37.5 \%$ of students can understand and use long and complicated English vocabulary while $62.5 \%$ of others can't understand and use long and complicated English vocabulary. It means that $62.5 \%$ of students have to improve their understanding of long and complicated English Vocabulary in order to be able to use it correctly.

\begin{tabular}{cc} 
Table 4 Students' Grammar Ability \\
\hline Answer Choice & Percentage \\
\hline Good & $0 \%$ \\
Medium & $87.5 \%$ \\
Bad & $12.5 \%$ \\
\hline Total & $\mathbf{1 0 0 \%}$ \\
\hline
\end{tabular}

Table 4 shows that $0 \%$ of students have good grammar ability. Then, $87.5 \%$ of students have medium grammar ability and $12.5 \%$ others have bad grammar ability. Since there are still $12.5 \%$ of students have the bad ability in grammar so they need to improve their ability in grammar because is also an important aspect in learning vocabulary. 
Table 5 Students can Make and Use Simple Present Tense Sentences

\begin{tabular}{cc}
\hline Answer Choice & Percentage \\
\hline Can & $66.7 \%$ \\
Can't & $33.3 \%$ \\
\hline Total & $\mathbf{1 0 0 \%}$ \\
\hline
\end{tabular}

Table 5 shows that $66.7 \%$ of students can make and use simple present tense sentences and $33.3 \%$ others can't make and use simple present tense sentences. It means that there are still $33.3 \%$ of students need to improve their ability in using simple present tense because this tense is often used in daily conversation.

Table 6 Students can Make and Use Simple Future Tense Sentences

\begin{tabular}{cc}
\hline Answer Choice & Percentage \\
\hline Can & $54.2 \%$ \\
Can't & $45.8 \%$ \\
\hline Total & $\mathbf{1 0 0 \%}$ \\
\hline
\end{tabular}

Table 6 shows that $54.2 \%$ of students can make and use simple future tense sentences and $45.8 \%$ others can make and use simple future tense sentences. Therefore, $54.2 \%$ of students need to improve their ability in using simple future tense because this tense is included in five basic tenses in English.

Table 7 Students can Make and Use Present Continuous Tense Sentences

\begin{tabular}{cc}
\hline Answer Choice & Percentage \\
\hline Can & $41.7 \%$ \\
Can't & $58.3 \%$ \\
\hline Total & $\mathbf{1 0 0 \%}$ \\
\hline
\end{tabular}

Table 7 shows that $41.7 \%$ of students can make and use present continuous tense sentences and $58.3 \%$ others can't make and use present continuous tense sentences. The number of students that can't make and use present continuous tense sentences is higher than the number of students that can make and use present continuous tense sentences. Therefore, they need to improve their ability in creating and using present continuous tense sentences and the lecturer may help them to do that.

Table 8 Students can Make and Use Present Perfect Tense Sentences

\begin{tabular}{cc}
\hline Answer Choice & Percentage \\
\hline Can & $41.7 \%$ \\
Can't & $58.3 \%$ \\
\hline Total & $\mathbf{1 0 0 \%}$ \\
\hline
\end{tabular}


Table 8 shows that $41.7 \%$ of students can make and use present perfect tense sentences and $58.3 \%$ others can't. The number of students that can't make and use present perfect tense sentences is higher than the number of students that can make and use present perfect tense sentences and therefore, the students need to improve their ability in creating and using this tense and the lecturer may help them to do so.

Table 9 Students Understood English Vocabulary

\begin{tabular}{cc}
\hline Answer Choice & Percentage \\
\hline Understood & $50 \%$ \\
Have not understood & $50 \%$ \\
\hline Total & $\mathbf{1 0 0 \%}$ \\
\hline
\end{tabular}

Table 9 shows that $50 \%$ of students understood English vocabulary and 50\% others have not understood English vocabulary and therefore, the students have to improve their comprehension in English vocabulary.

Table 10 Students Understood Synonym

\begin{tabular}{cc}
\hline Answer Choice & Percentage \\
\hline Understood & $50 \%$ \\
Have not understood & $50 \%$ \\
\hline Total & $100 \%$ \\
\hline
\end{tabular}

Table 10 shows that $50 \%$ of students understood synonym and $50 \%$ others have not understood synonym and therefore the students have to improve their comprehension in English synonym.

Table 11 Students Understood English Idioms

\begin{tabular}{cc}
\hline Answer Choice & Percentage \\
\hline Understood & $4 \%$ \\
Have not understood & $96 \%$ \\
\hline Total & $\mathbf{1 0 0 \%}$ \\
\hline
\end{tabular}

Table 11 shows that $4 \%$ of students understood English idioms and $96 \%$ others have not understood English idioms. The number of students who have not understood English idiom is higher than the number of students who understood English idiom and therefore, the students need to improve their comprehension of the English idiom.

Vocabulary is important in language skills. It is fundamental for the increase of other language skills such as reading comprehension, listening comprehension, 
speaking, writing, spelling, and pronunciation. Unfortunately, the questionnaires and interview result shows that students still have problems with vocabulary. Based on the interview with the English lecturer, it can be concluded that the students have very weak vocabulary skills. They have a very limited vocabulary, have difficulty memorizing the vocabulary given for telling about their daily routine, they can not make proper sentences without a dictionary.

When they have to make the same sentences without a dictionary, they will just give up as they do not remember the vocabulary. Then, students often mispronounce English words. The students also have difficulty in spelling English words correctly especially for "a", "I", and "e". Students do not understand long and complex words such as public health center, expired date, etc. as well as a theory mentioned that long words seem to be difficult to learn than short ones. But, as a rule of thumb, high-frequency words tend to be short in English, and therefore the learner is likely to meet them more often, a factor favoring their 'learnability' (Thornbury, 2004).

Grammar also becomes a problem for students in this research. Grammar associated with words is also problematic, especially if this differs from L1. Remembering whether a verb like enjoy, love, or hope is followed by an infinitive (to swim) or an -ing form (swimming) can be a difficulty for a student (Thornbury, 2004). According to the English lecturer, the students' grammar abilities were very poor. The problems of their grammar are tenses use, the plural form, and preposition. For example, they say "My class is in the second floor." They use 'in' instead of 'on'. In the simple present tense, the students cannot make a sentence properly. On the other hand, when they move to learn other tenses, they will get confused and forget what they have learned. Then, they still make mistakes in a plural sentence. They still get confused on how to make positive and interrogative sentences of simple present tense where they have to add $-\mathrm{s}$ or - es to the verb for the third singular person.

Students do not understand simple past tense as well. They cannot make simple past tense sentences correctly. Most of them still have problems with memorizing the past form of the verb, especially for irregular verbs. Students are 
able to make future tense sentences correctly. Unfortunately, when they have to make a sentence using an adjective or noun, they make errors by generalizing the rule. For example, they write "I will sick" instead of 'I will be sick'. The grammar problem which is the most frequent is tenses use especially simple present tense and simple past tense. Based on the interview with the English lecturer, it can be known that the students have problems with range, connotation, and idiom in English. They also have problem with translation. They are able to translate English vocabulary but they have to use a dictionary on their smartphone. They also have problems with range, connotation, and idiom in English.

\section{CONCLUSION}

Based on the finding and discussion, the researcher could draw the conclusions as follow: (1) The third-semester students of Food Technology Major of Tonggak Equator Polytechnic in the academic year of 2018-2019 still have low vocabulary ability; and (2) There are some vocabulary difficulties face by the students, they are: they have a very limited vocabulary; students often mispronounce English words. The students also still have difficulty in spelling English words correctly especially for 'a', 'I', and 'e'; students do not understand long and complex words such as public health center, expired date, fermentation, fish spoilage, etc.; and they also have problem with range, connotation, and idiom in English.

\section{REFERENCES}

Afzal, N. (2019). A study on vocabulary-learning problems encountered by BA English Majors at the university level of education. Arab World English Journal (AWEJ), 10(3), 81-98. https://dx.doi.org/10.24093/awej/ vol10no3.6.

Al-Hinnawi, A. N. (2012). The effect of the graphic organizer strategy on university students English vocabulary building. English Language Teaching, 5(12), 62-69. http://dx.doi.org/10.5539/elt.v5n12p62. 
Anil, B. (2011). Teaching vocabulary through games-a sanguine step. Journal on English Language Teaching, 1(4), 46-50.

Alqahtani, M. (2015). The importance of vocabulary in language learning and how to be taught. International Journal of Teaching and Education, 3(3), 21-34. http://dx.doi.org/10.20472/TE.2015.3.3.002.

Astika, I. G. (2016). Vocabulary learning strategies of secondary school students. IJOTL-TL: Indonesian Journal of Language Teaching and Linguistics, 1(1), 1-18. https://doi.org/10.30957/ijoltl.v1i1.1.

Bakhsh, S. A. (2016). Using game as a tool in teaching vocabulary to young learners. English Language Teaching, 9(7), 120-128. https://doi.org/ 10.5539/elt.v9n7p120.

Bin-Tahir, S. Z. (2015). Improving students' speaking skill through voice chat at University of Iqra Buru. Journal of Modern Education Review, 5(3), 296306. https://doi.org/10.15341/jmer(2155-7993)/03.05.2015/009.

Hancock, O. (1987). Reading skills for college students. New Jersey: PrenticeHall.

Hariyanto, \& Wulandari, F. (2019). An analysis of students' english vocabulary mastery and translation ability in senior high school. Edukasi: Jurnal Pendidikan, 17(2), 250-263. http://dx.doi.org/10.31571/edukasi.v17i2.1239.

Hatch, E., \& Brown, C. (1995). Vocabulary, semantics, and language education. New York: Cambridge University Press.

Lehr, F., Osborn, J., \& Hiebert, E. H. (2004). A focus on vocabulary. Honolulu, HI: Pacific Resources for Education and Learning.

Moeller, A. J., Ketsman, O., \& Masmaliyeva, L. (2009). The essentials of vocabulary teaching: From theory to practice. Diverse by Design. Central States Conference Report. Pp. 1-16. Carolyn Guiscoigne and Melanie Bloom, Editors, Eau Claire, WI: Crown Prints.

Nation, P. (2001). Teaching and learning vocabulary. New York: New House Publisher.

Nation, I. S. P. (2000). Learning vocabulary in another language. Cambridge: Cambridge University Press. 
Pyles, T. (1970). English: An introduction to language. San Diego: Harcourt College Pub.

Ramadhaniarti, T. (2016). Teaching English vocabulary through game: Views from students. Proceeding of the Fourth International Seminar on English Language and Teaching (ISELT-4) University of Bengkulu.

Salam, U. \& Nurnisa (2021). Students' difficulties in learning vocabularies. English Community Journal, 5(1), 46-53. https://doi.org/10.32502/ ecj.v5i1.3327.

Schmitt, N. (2000). Vocabulary in language teaching. Cambridge: Cambridge University Press.

Thornbury, S. (2004). How to Teach Grammar. Essex: Pearson Education Limited.

Thornbury, S. (2002). How to teach vocabulary. Harlow: Pearson Education Limited.

Viera, T. R. (2017). Vocabulary knowledge in the production of written texts: A case study on EFL language learners. Revista Tehnologica ESPOL, 30(3), 89-105.

Wilkins, D. (1972). Teaching vocabulary. https://www.tesol.org. Accessed at 9 December 2020. 